\title{
The Effect of Using Securitization on the Stability and the Risk of Banks: Evidence From Emerging Countries
}

\author{
Mohamed Rochdi Keffala ${ }^{1} \&$ Amal Farjaoui ${ }^{1}$ \\ ${ }^{1}$ High School of Computer Sciences and Management of Kairouan, University of Kairouan, Tunisia \\ Correspondence: Mohamed Rochdi Keffala, High School of Computer Sciences and Management of Kairouan, \\ University of Kairouan, Tunisia.
}

Received: November 22, 2019

Accepted: January 16, 2020

Online Published: March 17, 2020

doi:10.5430/ijfr.v11n2p205

URL: https://doi.org/10.5430/ijfr.v11n2p205

\begin{abstract}
The purpose of this study is to investigate whether securitization affect financial stability and risk of banks issued from emerging countries during the period 2007 to 2017.

To reach this end we conduct dynamic panel data econometrics with Generalized Methods of Moments (GMM) system on 20 banks issued from emerging countries. The dependent variables are defined by "Bank Stability Index" (BSI) and "logarithm of z-score" and ratios of total risk and credit risk. The independent variables are split into variable of interest (securitization ratio), bank-specific variables (capital adequacy, profitability, on-balance sheet interest rate risk, financial margin, income diversification, liquidity and bank size) and country-specific variables (GDP and inflation).
\end{abstract}

As major conclusion, we find that using securitization - by banks from emerging countries - enhances their financial stability and minimizes their total risk and credit risk.

As a practical contribution to this work, we suggest that banks' decision-makers in emerging countries increase their use of securitization in order to benefit from its beneficial effect on their financial stability and risks.

Keywords: banks, securitization, financial stability, risk, emerging countries

JEL classification: G21, G32

\section{Introduction}

For several years, the financial system of several countries has entered a phase of profound changes at the origin of two major phenomena namely new technologies and deregulation. This metamorphosis of the financial environment has led financial institutions to create new financial products based on these new and regulatory technologies called financial innovations. Among the financial innovations most used by banks in recent decades, there are securitization products.

The first securitization transactions were carried out in the United States in the 1970s. Since the securitization field has continued to expand and these operations are developing in many countries whether developed or emerging.

The use of securitization offers many advantages, especially that of credit risk coverage.

As a result, there has been a remarkable increase in the use of securitization mainly by financial institutions in recent decades. This trend has become more widespread in emerging countries. In fact, for example, the securitization amount used by First Rand Bank in South Africa increased from 1395 million US dollars (USD) in 2007 to 2540 million in 2012 and finally reached 2383 million USD in 2017 (Note 1). Similarly, Banco Banco Bancomer de Mexico issued ABS in 2007 amounting to USD 919 million, which has increased almost sevenfold to USD 6473 million in 2017 (Note 2). Also, for the Lebanese bank FransaBank the use of securitization has clearly increased. In fact, the securitization amount was equivalent to USD 724 million in 2007, the equivalent of $31 \%$ of the credits granted by the bank. In ten years, this amount has increased considerably to finally reach 15194 million dollars in 2017 (Note 3).

However, this success of the use of securitization was marred during the last financial crisis called "subprime". Certainly, several voices have accused the different securitization products of being responsible for the propagation or even the proliferation of this crisis of the United States to several developed but also emerging countries. 
However, emerging countries suffer from the fragility of their financial systems, so banks from these countries could run a risk through the use of securitization products.

From this observation emerges our motivation to study the impact of the use of securitization on the financial stability and risk of banks from emerging countries. Hence our problem:

How does the use of securitization by banks from emerging countries affect their financial stability and risk?

Thus, our work has the aim to examine empirically the effect of the use of securitization on financial stability and risk of banks from emerging countries.

This research contributes to the related literature. In fact, this piece fulfills the huge gap in the literature by investigating the effect of securitization on the stability and risk of banks issuing from emerging countries.

As conclusion, our main findings reveal that using of securitization by sample banks improves their stability -on one hand- and diminishes their total risk and credit risk - on the other hand.

The remaining of this work is planned as follows: Section 2 gives description of the sample based on statistics. Section 3 provides review of literature and exposes hypotheses. Section 4 explains the methodology. In Section 5, results are presented, analyzed and commented. Section 6 summarizes the main results. Finally, Section 7 concludes and provides implications.

\section{Sample Description and Statistics}

In order to obtain a sufficient data set and according to the availability of the data, we kept a sampling period from 2007 to 2017.

The constitution of the sample is constrained by the simultaneous meeting of the following three conditions:

1. Bank from emerging countries

2. Bank using securitization

3. Availability of data about the annual amounts of securitization carried out during the period between 2007 and 2017.

As a result, we conducted a long screening of banks that met these criteria. At the end of this selection, we selected 20 banks from emerging countries and three regions:

- the countries of South America (Mexico, Argentina, Brazil, Colombia),

- Asian countries (Kuwait, the United Arab Emirates, Lebanon, China, Taiwan, South Korea, the Philippines and India)

- and Africa represented by South Africa.

The Table 1 below exposes the name of banks with their hyperlinks to web sites, their labels and their countries.

Table 1. Sample presentation

\begin{tabular}{lll}
\hline Name & Label & Country \\
\hline Banco National de México & Banamex & Mexico \\
\hline Banco Bilbao Vizcaya Argentaria de Comercio & Bancomer & Mexico \\
\hline Banco Hipotecario & Hipotecario & Argentina \\
\hline CAIXA BANK & CAIXA & Brazil \\
\hline Banco Itau & Itau & Brazil \\
\hline Banco Davivienda & Davivienda & Colombia \\
\hline Ahli United Bank & AUB & Kuwait \\
\hline National Bank of Dubai & NBD & United Arab Emirates \\
\hline National Bank Abu Dhabi & NBAD & United Arab Emirates \\
\hline FransaBank & Fransa & Lebanon \\
\hline Industial and Commercial Bank of chine Limited & ICBC & China \\
\hline
\end{tabular}




\begin{tabular}{lll}
\hline Bank of taiwan & BOT & Taiwan \\
\hline Koria Bank Financial Group & KBFG & South Korea \\
\hline LandBank & Land & Philippines \\
\hline Industrial Credit and Investment Corporation of India & ICICI & India \\
\hline State Bank of India & SBI & India \\
\hline NedBank Group & Ned & South Africa \\
\hline Amalgamated Banks of South Africa & ABSA & South Africa \\
\hline FirstRand Bank & FirstRand & South Africa \\
\hline Standard Bank of South Africa & SBSA & South Africa \\
\hline
\end{tabular}

As following, the Figure 1 shows the evolution of secuirtization of the entire sample during the period 2007-2017.

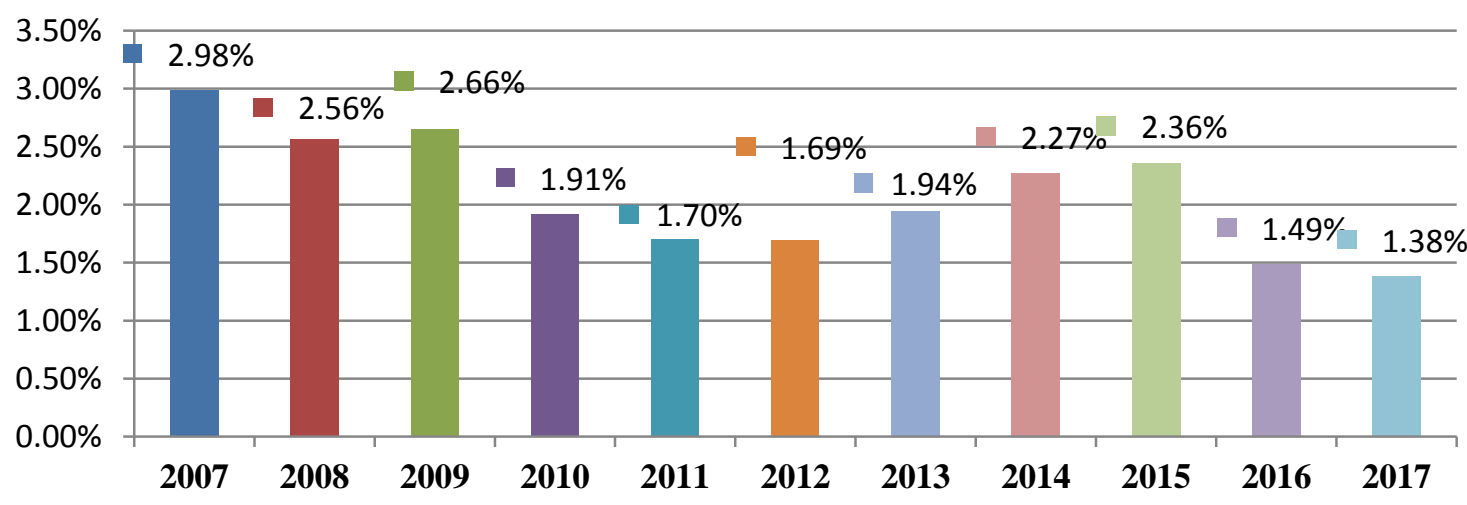

Figure 1. Evolution of securitization of the overall sample banks

The Figure 1 above describes the evolution of the securitization ratio (measured by total carrying amount of securitization divided by total loans) of the entire sample during the average period from 2007 to 2017.

From this figure, we detect that the part of securitization does not exceed 3\% of total loans. Therefore, we deduce that sample banks do not devote high proportion for securitization.

On the other hand, we observe noticeably a decrease of the use of securitization from 2007 to 2017 despite an increase during the subperiod 2013-2015. Indeed, the average percentage of securitization per total loans is falled from $2.98 \%$ in 2007 to $1.38 \%$ in 2017. This result can be explained by the implication of last financial crisis. In fact, during this period a common debate has discussed the implication of financial innovations and especially securitized instruments in the accentuation and the propagation of the last financial crisis. For this reason, we think that sample banks decided to minimize their use of securitization. At last, from the Figure 1 above we notice that in general sample banks use securitization

As following, the Figure 2 explains the evolution of securitization during the period 2007-2017 of each bank of the sample. 


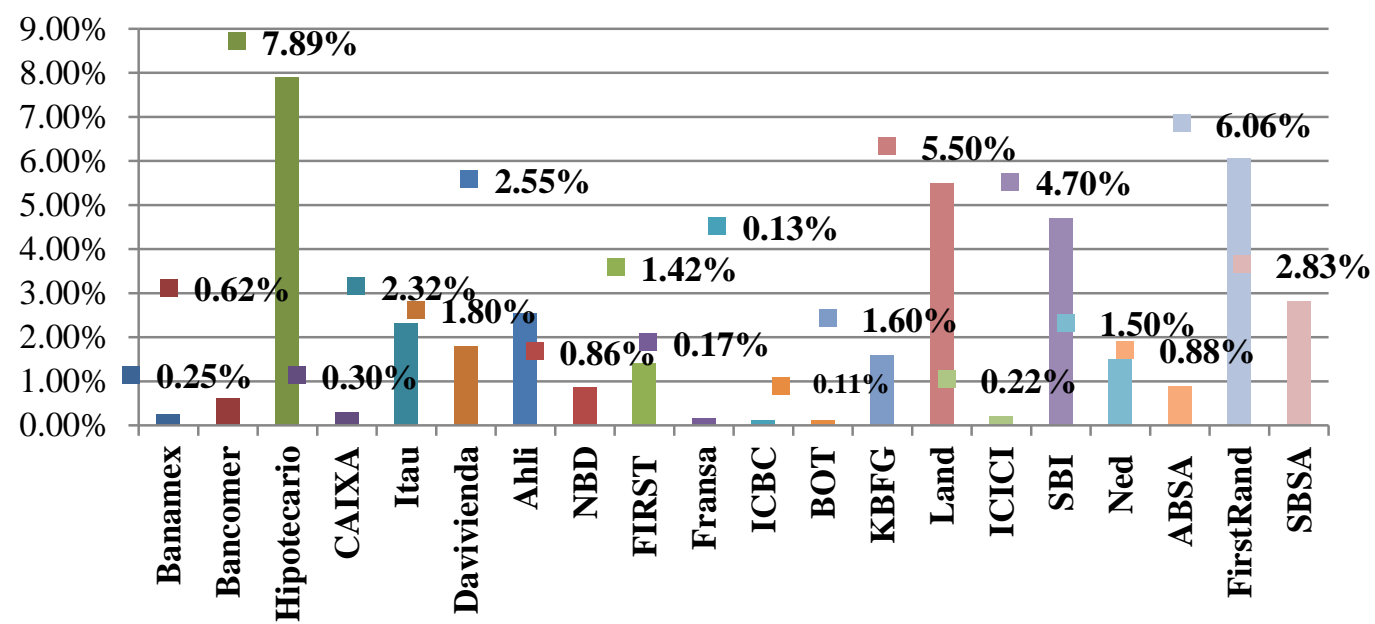

Figure 2. Evolution of securitization of each sample bank

The Figure 2 above shows that Hipotecario is the biggest user of securitization. In fact, Hippotecario has a percentage of securitization per total assets equals to 7.89\% during the average period 2007-2017. In addition, we state that FirstRand, Land and SBI use moderately securitization with percentages respectively equal to $6.06 \%, 5.5 \%$ and $4.7 \%$. On the other hand, we remark that the part of securitization per total loans of almost the half of the sample does not exceed 1\%. Indeed, ABSA, NBD, Bancomer, CAIXA, Banamex, ICICI, Fransa, ICBC, and BOT use slightly securitization with percentages equal respectively to $0.88 \%, 0.86 \%, 0.62 \%, 0.30 \%, 0.25 \%, 0.22 \%, 0.17 \%$, $0.13 \%$ and $0.11 \%$.

In summary, and according to the Figure 1, we deduce clearly from the Figure 2 that the amount of securitization used by sample banks is relatively slight.

\section{Literature Review}

\subsection{Effect of Securitization on Banking Stability}

Instefjord (2005) deduce that the effect of securitization on the strength of the bank depends on the level of risk of taking on new assets.

Wagner (2007) has shown that the liquidity of bank assets obtained through securitization increases the instability and externalities associated with bank failures.

Uzun and Webb (2007) examined the impact of securitization on bank stability using data from a sample of 112 financial institutions in the United States for the period 2001 to 2005. Their results indicate that securitization is negatively related to the financial stability of the issuing bank.

Dionne and Harchaoui (2003) found that an increase in the volume of securitization of credit risk has a negative impact on the quality of assets, acting as an indicator of financial strength, of issuing banks.

Jiangli and Pritsker (2008) studied the effect of mortgage securitization on stability using data from US banks over the period from 2001 to 2007. They found that MBS tend to increase financial strength of the bank.

Michalak and Uhde (2012) tested the impact of credit risk securitization on the financial stability of banks, for a sample of 60 banks listed on the stock exchange in the EU and Switzerland, over the period from 1997 to They concluded that the securitization of credit risk has a negative impact on the financial stability of listed European banks.

Patti and Sette (2016) examined the impact of securitization on banks' behavior during the 2007-2008 financial crisis. They found that increasing banks' credit supply capacity through securitization can pose a risk to their financial stability by weakening monetary policy.

González et al. (2016), studied the effect of the use of securitization on the stability of the banking sector, for a sample of 134 European listed banks over the period from 2006 to 2010. They found that securitization has a 
negative effect on financial stability.

Deku et al. (2019), studied the effects of securitization on the behavior of banks in emerging countries, such as Latin America and China, and its impact on financial stability. They noted that securitization has led to imbalances in credit markets, which have increased the fragility of the financial system and thus reduced financial stability.

\subsection{Effect of Securitization on Bank Risk}

Kahane (1977) and Kohen and Santomero (1980) found that securitization increases the risk of bank failure.

Aggarwal and Jacques (2001), Cabiles (2011), Gorton and Pennachi (1995) and Lutskina (2011) found a positive relationship between securitization and credit risk. Thus, they conclude that using securitization increase credit risk.

Using data from a sample of 10 Canadian banks, Dionne and Harchaoui (2003) measured banks' insolvency risk based on regulatory capital ratios relative to risk-weighted assets. They found that securitization is associated with a decline in banks' capital ratios, which increases the risk of insolvency.

Franke and Krahnen (2005) find that banks increase their risk profile by using securitization.

Hansel and Krahnen (2007), based on 49 international banks listed in Europe from January 1997 to December 2004, tested the effect of the use of securitization products on risk-taking. They found that the issuance of CDOs tends to increase the systematic risk of the issuing bank.

Other papers such as Lockwood et al. (1996) Hansel and Krahnen (2007), and Farhi and Tirole (2009) have found that using securitization increase systematic risk.

Jiangli and Pritsker (2008) found that US banks that are active in the securitization market tend to have lower insolvency risk and also higher profitability compared to non-active banks in this market. They conclude that securitization increases bank profitability while reducing the overall risk of insolvency.

Similarly, Jiangli and Pritsker (2008) used 2001-2007 data to assess the impact of mortgage securitization on the insolvency risk and profitability of US banks. They found that securitization techniques reduce the risk of insolvency and thus increase banks' profitability.

Panetta and Pozzolo (2010) conducted an empirical study that analyzes the consequences of securitization, using a large sample of banks from more than 100 countries around the world over a relatively long period from 1991 to 2007. They concluded that banks that use securitization transactions are primarily large, profitable banks and reduce their credit risk by expanding their exposure to liquidity risk and improving their capital ratios.

Batten and Hogan (2002), Morgan (2006), Mengle (2007), Angelini (2012) and Rodriguez et al. (2015) found that securitization products help reduce bank risk and offer the best diversification.

Battaglia and Gallo (2013) examined the relationship between asset securitization and risk measures, using a sample of 21 Italian banks over the period 2000 to 2009. They showed that securitization increases the behavior risk taking banks and that banks using this operation are likely to contribute more in the event of a systemic crisis.

Farruggio and Uhde (2015) found a negative relationship between credit risk and securitization volume for a sample of CDOs issued by 75 European listed banks for a period from 1997 to 2010.

Mokatsanyane and Viljoen (2017) examined the relationship between credit risk and securitization in the banking sector in South Africa for a period from 2005 to 2014 and using a sample containing four South African banks, namely ABSA Bank, First Rand Bank, NedBank and Standard Bank. The results reveal an increase in credit risk when banks use more securitization transactions.

\subsection{Hypotheses}

Following a literature review of studies that have empirically examined the effect of securitization on financial stability, we can deduce that several studies have concluded that the use of securitization decreases the financial stability of banks.

In fact, Dionne and Harchaoui (2003) found that the increase in the volume of receivables securitization has a negative impact on the quality of the assets and consequently on the financial strength of the issuing banks.

In addition, Wagner (2007) showed that the liquidity of bank assets obtained through securitization increases the instability associated with bank failures.

In the same view, Shin (2009) has shown that securitization has not improved financial stability as a result of declining credit quality and the financial crisis. 
Similarly, Michalak and Uhde (2012) provided empirical evidence that the securitization of credit risk has a negative impact on the financial stability of the sixty European listed banks over the period from 1997 to 2007.

Add to that, González et al. (2016), found that securitization has a negative effect on the financial stability of 134 listed European banks over the period from 2006 to 2010.

More recently, Deku et al. (2019), found that securitization led to imbalances in credit markets, which increased the fragility of the financial system and thus reduced the financial stability of banks in Latin America and China during the financial crisis.

Therefore, and in light of the conclusions of this work, we stipulate the following research hypothesis:

H1: The use of securitization decreases the financial stability of banks from emerging countries

Based on the review of the literature on the effect of securitization on bank risk, we can deduce that the majority of studies have found that the use of securitization increases bank risk.

In fact, studies by Kohen and Santomero (1980) found that securitization increases the bank's risk of default and decreases the trust of these clients, which will affect the repayment system and thus increase the credit risk.

We can also cite the work of Hansel and Krahnen (2007), who found that the issuance of CDOs by 49 international banks listed in Europe over the period from January 1997 to December 2004 tends to increase the systematic risk of the bank Issuer.

In addition, Gorton and Metrick (2012) found that the negative economic consequences of increased systemic risk are caused by securitization during the 2007-2008 financial crisis.

Finally, Mokatsanyane and Viljoen (2017) concluded that securitization amplifies banks' risk of their samples for the period from 2005 to 2014.

Thus, in light of these conclusions, we propose the following research hypothesis:

H2: The use of securitization increases the risk of banks from emerging countries.

\section{Methodology}

\subsection{Variables Description}

In this subsection, dependent variables used in our panels are described as follows:

\subsubsection{Description of Stability Measures}

After a review of the literature, we decide to construct "Bank Stability Index" as developed by Ghosh (2010) and to calculate "logarithm of z-score" according to Chiaramonte et al. (2015).

Indeed, we stay that the most of papers have used two ranges of bank stability measures: z-score and bank stability index.

On the one hand, the first range of papers such as the papers of Ivičić et al. (2008); Laeven and Levine (2009); Liu et al. (2010), Chiaramonte et al. (2015), Kasman and Carvallo (2014), Fu et al. (2014), and Kasman and Kasman (2015) has measured bank stability by z-score.

The z-score reflects the number of standard deviations by which returns would have to fall from the mean in order to wipe out bank equity. Higher values of z-score are indicative of lower probability of insolvency risk and greater bank stability. The formula of $\mathrm{z}$-score is as follows:

$$
\text { z-score: } z \text {-score }=[\text { ROA + EQTA }] / \text { stdROA }
$$

Since the $\mathrm{z}$-score is highly skewed, we use the natural logarithm of the $\mathrm{z}$-score according to the studies of and Chiaramonte et al. (2015).

On the other hand, the second range of the papers construct bank stability index. Illing and Liu $(2003,2006)$ developed a Financial Stress Index for the Canadian financial system. The index provided a single measure of macroeconomic financial stress, which they allowed to vary over a continuum of values, where extreme values reflect crises.

The study conducted a survey on Canadian policymakers and economists, whose responses fed into the model to determine the events that were most stressful for Canada. They constructed a weighted average of various indicators of expected loss, risk, and uncertainty in the financial sector. The resulting financial stress index (FSI) is a continuous, broad-based measure that includes the following indicators from equity, bond, and foreign exchange 
markets, as well as indicators of banking sector performance.

Van den End (2006) advanced a financial stability condition index for the Netherlands. This index incorporated interest rates, effective exchange rate, real estate and stock prices, solvency of the financial institutions, as well as volatility of the stock index of financial institutions.

Gersl and Hermanek (2006) constructed an aggregate financial stability indicator based on the values of the IMF's core FSIs for the Czech National Bank. Similarly, the Central Bank of the Republic of Turkey (2006) constructed a financial strength index. The bank used six sub-indices covering capital adequacy, asset quality, liquidity, profitability, foreign exchange and interest rate risks. Segoviano and Goodhart (2009) develop a Banking Stability Index (BSI), on the basis of non-linear and dynamic dependencies.

Albulescu (2010) constructed an aggregate stability index for the Romanian financial system. The index composed of developments in the financial system, vulnerability, soundness and international economic climate indicators.

Ghosh (2010) develops a bank-wise stability index, taking on board major aspects of banking operations. These aspects of banking operation are splitting into three major dimensions which are: profitability, soundness and stability.

Morris (2011) developed an aggregate financial stability index for Jamaica using banking system quarterly data over the period 1997 to March 2010. This index aggregated microeconomic, macroeconomic and international factors indicative of banking sector performance into a single measure of financial stability. The index was successful in capturing key periods of financial instability during the sample period.

Based on Cooperative banks in OECD countries Chiaramonte et al. (2013) have constructed in their study bank stability index according to Ghosh (2010).

The study of Sere-Ejembi et al. (2014) adapts approach to constructing bank stability index for Nigeria. The approach combines banking soundness, vulnerabilities in the macro-economy and the influence of the external financial environment.

After this theoretical review about bank stability index, we prefer to follow the methodology used by Ghosh (2010) because we think that is less sophisticated than the index used by the others studies.

Due to its simplicity and robustness we decide to follow the methodology of Ghosh (2010).

According to Ghosh (2010) Bank Stability Index (BSI) is constructed from three major dimension of banking operation i.e. profitability, soundness and stability.

Ghosh (2010) used the following three indicators of banking operations:

(1) Loan-loss provisions (LLP) to total asset ratio.

(2) Total capital to total risk weighted asset ratio, or capital adequacy ratio.

(3) Profitability return on asset (ROA), measured as profit after tax to total asset ratio.

To construct the BSI, Ghosh (2010) proceeded as follows. For any indicator i, the index for the ith dimension, di, is given by the expression:

$$
\mathrm{d}_{\mathrm{i}}=\frac{\mathrm{A}_{\mathrm{i}}-\mathrm{m}_{\mathrm{i}}}{\mathrm{M}_{\mathrm{i}}-\mathrm{m}_{\mathrm{i}}}
$$

With $\mathrm{A}$ is the actual, $\mathrm{M}$ and $\mathrm{m}$ are the maximum and minimum value of dimension i. As clarified by Ghosh (2010), higher values of $d_{i}$ would suggest higher levels of achievement by the bank in the given dimension. Ghosh (2010) defined the index in the $n$-dimensional space by the following equation (2):

$$
\mathrm{BSI}_{\mathrm{j}}=1-\frac{\sqrt{\sum_{\mathrm{i}=1}^{\mathrm{n}}\left(1-\mathrm{d}_{\mathrm{i}}\right)^{2}}}{\sqrt{\mathrm{n}}}
$$

\subsubsection{Description of Risk Measures}

The total risk is measured by the standard deviation of the ROA calculated on a three-year delay. This measure was adopted by Agusman et al. (2008) and later reviewed by Chiaramonte et al. (2015).

Credit risk is represented by three ratios: 
- The total debt ratio (GL) divided by total assets.

This ratio expresses the lending behavior of the bank. Higher values of this ratio indicate weak lending behavior and therefore a higher proportion of credit risk.

- Loan loss provision ratio (LLP) divided by total receivables. This ratio indicates the loss of reserves due to borrowings. Higher LLP values increase credit risk. This ratio is a relevant indicator of credit risk, as expressed by Chiaramonte et al. (2013).

- The ratio of total nonperforming loans (NLP) divided by total receivables. This ratio measures the share of bad and doubtful loans in total loans. Higher proportions of NPLs increase credit risk.

4.1.3 Variables Explanation

The Table 2 as following gives explanation of dependent variables:

Table 2. Explanation of dependent variables

\begin{tabular}{llll}
\hline Definitions & & Labels & Modes of calculation \\
\hline \multirow{2}{*}{ Stability } & Bank Stability Index & BSI & See page 9 \\
\cline { 2 - 4 } & Logarithm of z-score & LNZSCORE & See page 8 \\
\hline \multirow{nyyy}{*}{ Total risk } & SDROA & $\begin{array}{l}\text { The standard deviation of return on assets of three } \\
\text { years lagged }\end{array}$ \\
\cline { 2 - 4 } & Credit risk 1 & GL & The ratio of total gross loan divided by total assets \\
\cline { 2 - 4 } & Credit risk 2 & LLP & $\begin{array}{l}\text { The ratio of loan loss provisions divided by total } \\
\text { gross loans }\end{array}$ \\
\cline { 2 - 4 } & Credit risk 3 & NPL & $\begin{array}{l}\text { The ratio of the non-performing loans divided by } \\
\text { total gross loans }\end{array}$ \\
\hline
\end{tabular}

The Table 3 below explains the explanatory variables used in the regressions:

Table 3. Explanation of explanatory variables

\begin{tabular}{|c|c|c|c|}
\hline Definitions & & Labels & Modes of calculation \\
\hline Securitization & & SEC & The ratio of securitization divided by total gross loans \\
\hline \multirow{9}{*}{$\begin{array}{l}\text { Bank-specific } \\
\text { variables }\end{array}$} & Capital adequacy & CAD & The ratio of total equity divided by total assets \\
\hline & Liquidity & LIQ & The ratio of liquid assets divided by total assets \\
\hline & \multirow[t]{2}{*}{ Profitability } & ROE & $\begin{array}{l}\text { The ratio of return-on-equity equals to net incomes } \\
\text { divided by total equities }\end{array}$ \\
\hline & & ROA & $\begin{array}{l}\text { The ratio of return-on-assets equals to net incomes } \\
\text { divided by total assets }\end{array}$ \\
\hline & Efficiency & CIR & $\begin{array}{l}\text { The ratio of cost-to-income equals to operating costs } \\
\text { divided by operating revenues }\end{array}$ \\
\hline & Margine & NIM & The ratio of net interest income divided by total assets \\
\hline & $\begin{array}{l}\text { On-balancesheet } \\
\text { interest rate risk }\end{array}$ & NONIM & The ratio of non-interest incomes divided by total assets \\
\hline & Income diversification & DIV & $\begin{array}{l}\text { The ratio of non interest income divided by net operating } \\
\text { incomes }\end{array}$ \\
\hline & BanK size & SIZE & $\begin{array}{l}\text { The size is calculated using Napierian logarithm of total } \\
\text { assets for each bank expressed in millions of US dollars }\end{array}$ \\
\hline Country-specifc & Gross domestic product & GDP & Annual percentage change of Gross Domestic Product \\
\hline variables & Inflation & INF & Annual percentage change of Inflation rate \\
\hline
\end{tabular}




\subsection{Model}

The conceptual model is defined by the following general equation :

(Stability, Risk $)=\mathrm{f}($ Securitization, control variables)

Thus, the model is divided into two panels defined by the following general equations:

Panel A: Stability $=\mathrm{f}$ (Securitization, control variables)

Panel B: Risk $=\mathrm{f}$ (Securitization, control variables)

The stability is measured by two variables: BSI and LNZSCORE for this reason two sub-panels are defined in the Table 4 below:

Table 4. Panel A explanation

\begin{tabular}{|c|c|c|}
\hline Panel & Dependent variable & Model \\
\hline $\mathrm{A} 1$ & BSI & $\begin{array}{l}\mathrm{BSI}_{\mathrm{i}, \mathrm{t}}=\gamma_{0}+\gamma_{1} \mathrm{SEC}_{\mathrm{i}, \mathrm{t}}+\gamma_{2} \mathrm{CAD}+\gamma_{3} \mathrm{LIQ}_{\mathrm{i}, \mathrm{t}}+\gamma_{4} \mathrm{ROE}_{\mathrm{i}, \mathrm{t}}+\gamma_{5} \mathrm{ROA}_{\mathrm{i}, \mathrm{t}}+\gamma_{6} \mathrm{EFF}_{\mathrm{i}, \mathrm{t}} \\
+\gamma_{7} \mathrm{NIM}_{\mathrm{i}, \mathrm{t}}+\gamma_{8} \mathrm{NONIM}_{\mathrm{i}, \mathrm{t}}+\gamma_{9} \mathrm{DIV}_{\mathrm{i}, \mathrm{t}}+\gamma_{10} \mathrm{SIZE}_{\mathrm{i}, \mathrm{t}}+\gamma_{11} \mathrm{GDP}_{\mathrm{i}, \mathrm{t}}+\gamma_{12} \mathrm{INF}_{\mathrm{i}, \mathrm{t}}+ \\
\left(\mathrm{u}_{\mathrm{i}}+\mathrm{e}_{\mathrm{i}, \mathrm{t}}\right)\end{array}$ \\
\hline A2 & LNZSCORE & $\begin{array}{l}\text { LNZSCORE }_{\mathrm{i}, \mathrm{t}}=\gamma_{0}+\gamma_{1} \mathrm{SEC}_{\mathrm{i}, \mathrm{t}}+\gamma_{2} \mathrm{LIQ}_{\mathrm{i}, \mathrm{t}}+\gamma_{3} \mathrm{ROE}_{\mathrm{i}, \mathrm{t}}+\gamma_{4} \mathrm{EFF}_{\mathrm{i}, \mathrm{t}}+\gamma_{5} \mathrm{NIM}_{\mathrm{i}, \mathrm{t}}+ \\
\gamma_{6} \mathrm{NONIM}_{\mathrm{i}, \mathrm{t}}+\gamma_{7} \mathrm{DIV}_{\mathrm{i}, \mathrm{t}}+\gamma_{8} \mathrm{SIZE}_{\mathrm{i}, \mathrm{t}}+\gamma_{9} \mathrm{GDP}_{\mathrm{i}, \mathrm{t}}+\gamma_{10} \mathrm{INF}_{\mathrm{i}, \mathrm{t}}+\left(\mathrm{u}_{\mathrm{i}}+\mathrm{e}_{\mathrm{i}, \mathrm{t}}\right)\end{array}$ \\
\hline
\end{tabular}

On the other hand, the risk is defined as total risk and credit risk:

Total risk is measured by standard deviation of ROA with three years lagged (SDROA).

Credit risk is measured by three ratios as follows:

- The ratio of gross loans divided by total assets (GL).

- The ratio of loan loss reserves divided by total loans (LLP).

- The ratio of non-performing loans divided by total loans (NPL).

Panel B is explained by the Table 5 below:

Table 5. Panel B explanation

\begin{tabular}{|c|c|c|}
\hline Panel & Dependant variable & Model \\
\hline B1 & SDROA & $\begin{array}{l}\text { SDROA }_{i, t}=\gamma_{0}+\gamma_{1} \text { SEC }_{i, t}+\gamma_{2} \text { CAD }+\gamma_{3} \text { LIQ }_{i, t}+\gamma_{4} \text { ROE }_{i, t}+\gamma_{5} \text { EFF }_{i, t}+\gamma_{6} \text { NIM }_{i, t}+ \\
\gamma_{7} \text { NONIM }_{i, t}+\gamma_{8} \text { DIV }_{i, t}+\gamma_{9} \text { SIZE }_{i, t}+\gamma_{10} \text { GDP }_{i, t}+\gamma_{11} \text { INF }_{i, t}+\left(u_{i}+e_{i, t}\right)\end{array}$ \\
\hline B2 & GL & $\begin{array}{l}\mathrm{GL}_{\mathrm{i}, \mathrm{t}}=\gamma_{0}+\gamma_{1} \mathrm{SEC}_{\mathrm{i}, \mathrm{t}}+\gamma_{2} \mathrm{CAD}+\gamma_{3} \mathrm{LIQ}_{\mathrm{i}, \mathrm{t}}+\gamma_{4} \mathrm{ROE}_{\mathrm{i}, \mathrm{t}}+\gamma_{5} \mathrm{ROA}_{\mathrm{i}, \mathrm{t}}+\gamma_{6} \mathrm{EFF}_{\mathrm{i}, \mathrm{t}}+\gamma_{7} \\
\mathrm{NIM}_{\mathrm{i}, \mathrm{t}}+\gamma_{8} \mathrm{NONIM}_{\mathrm{i}, \mathrm{t}}+\gamma_{9} \mathrm{DIV}_{\mathrm{i}, \mathrm{t}}+\gamma_{10} \mathrm{SIZE}_{\mathrm{i}, \mathrm{t}}+\gamma_{11} \mathrm{GDP}_{\mathrm{i}, \mathrm{t}}+\gamma_{12} \mathrm{INF}_{\mathrm{i}, \mathrm{t}}+\left(\mathrm{u}_{\mathrm{i}}+\mathrm{e}_{\mathrm{i}, \mathrm{t}}\right)\end{array}$ \\
\hline B3 & LLP & $\begin{array}{l}\mathrm{LLP}_{\mathrm{i}, \mathrm{t}}=\gamma_{0}+\gamma_{1} \mathrm{SEC}_{\mathrm{i}, \mathrm{t}}+\gamma_{2} \mathrm{CAD}+\gamma_{3} \mathrm{LIQ}_{\mathrm{i}, \mathrm{t}}+\gamma_{4} \mathrm{ROE}_{\mathrm{i}, \mathrm{t}}+\gamma_{5} \mathrm{ROA}_{\mathrm{i}, \mathrm{t}}+\gamma_{6} \mathrm{EFF}_{\mathrm{i}, \mathrm{t}}+\gamma_{7} \\
\mathrm{NIM}_{\mathrm{i}, \mathrm{t}}+\gamma_{8} \mathrm{NONIM}_{\mathrm{i}, \mathrm{t}}+\gamma_{9} \mathrm{DIV}_{\mathrm{i}, \mathrm{t}}+\gamma_{10} \mathrm{SIZE}_{\mathrm{i}, \mathrm{t}}+\gamma_{11} \mathrm{GDP}_{\mathrm{i}, \mathrm{t}}+\gamma_{12} \mathrm{INF}_{\mathrm{i}, \mathrm{t}}+\left(\mathrm{u}_{\mathrm{i}}+\mathrm{e}_{\mathrm{i}, \mathrm{t}}\right)\end{array}$ \\
\hline B4 & NPL & $\begin{array}{l}\mathrm{NPL}_{\mathrm{i}, \mathrm{t}}=\gamma_{0}+\gamma_{1} \mathrm{SEC}_{\mathrm{i}, \mathrm{t}}+\gamma_{2} \mathrm{CAD}+\gamma_{3} \mathrm{LIQ}_{\mathrm{i}, \mathrm{t}}+\gamma_{4} \mathrm{ROE}_{\mathrm{i}, \mathrm{t}}+\gamma_{5} \mathrm{ROA}_{\mathrm{i}, \mathrm{t}}+\gamma_{6} \mathrm{EFF}_{\mathrm{i}, \mathrm{t}}+\gamma_{7} \\
\mathrm{NIM}_{\mathrm{i}, \mathrm{t}}+\gamma_{8} \mathrm{NONIM}_{\mathrm{i}, \mathrm{t}}+\gamma_{9} \mathrm{DIV}_{\mathrm{i}, \mathrm{t}}+\gamma_{10} \mathrm{SIZE}_{\mathrm{i}, \mathrm{t}}+\gamma_{11} \mathrm{GDP}_{\mathrm{i}, \mathrm{t}}+\gamma_{12} \mathrm{INF}_{\mathrm{i}, \mathrm{t}}+\left(\mathrm{u}_{\mathrm{i}}+\mathrm{e}_{\mathrm{i}, \mathrm{t}}\right)\end{array}$ \\
\hline
\end{tabular}

\subsection{Method}

We use dynamic panels defined by the technique of Generalized Methods of Moments (GMM) in order to have more robustness and relevance in estimating regressions. GMM is developed first by Arellano and Bover (1995) and proposed then by Blundell and Bond (1998).

Compared to traditional econometric methods (OLS regressions), GMM solves the endogeneity problem in the independent variables using a series of instrumental variables generated by lagged variables. Additionally, GMM estimator technique is used by many previous studies (see for example Farhi and Borghi, 2009; Chiaramonte et al., 2013; Sun et al., 2017). 


\section{Results}

\subsection{Presentation of Results}

As following the Table 6 shows panel regressions which are conducted with two-step system GMM estimator with postestimation tests (Sargan test and Arrellano \& Bond test) during the period 2007-2017.

Table 6. GMM Regression results during the overall period 2007-2017

\begin{tabular}{|c|c|c|c|c|c|c|}
\hline \multirow{3}{*}{$\begin{array}{l}\text { Dependent variables } \\
\text { Explanotory variables }\end{array}$} & \multirow{2}{*}{\multicolumn{2}{|c|}{ Stability measures }} & \multicolumn{4}{|l|}{ Risk measures } \\
\hline & & & \multirow{2}{*}{$\begin{array}{l}\text { Total risk } \\
\text { SDROA (Panel B1) }\end{array}$} & \multicolumn{3}{|l|}{ Credit risk } \\
\hline & BSI (Panel A1) & LNZSCORE (Panel A2) & & GL (Panel B2) & LLP (Panel B3) & NPL (Panel B4) \\
\hline \multirow{2}{*}{ SEC } & $0.05704 *$ & $21.56117^{*}$ & $-0.00403 * *$ & $-2.10083^{*}$ & $-0.07029^{*}$ & 0.36055 \\
\hline & $(0.03176)$ & $(13.49008)$ & $(0.00190)$ & $(1.14585)$ & $(0.04177)$ & $(0.34100)$ \\
\hline \multirow{2}{*}{ CAD } & $0.24440^{* * *}$ & ND & $0.01527^{* * *}$ & $-4.72678^{*}$ & $-0.29013^{*}$ & 0.89566 \\
\hline & $(0.06463)$ & & $(0.00649)$ & (2.80766) & $(0.15742)$ & $(0.88820)$ \\
\hline \multirow{2}{*}{ LIQ } & 0.0049624 & -2.855105 & $0.00530^{* *}$ & $-0.46796 * *$ & 0.01847 & -0.02356 \\
\hline & $(0.00681)$ & $(4.18395)$ & $(0.00238)$ & $(0.19801)$ & $(0.01747)$ & $(0.11262)$ \\
\hline \multirow{2}{*}{ NIM } & 0.09796 & 21.48254 & $0.04476^{* * *}$ & -0.98624 & -0.02626 & 1.341977 \\
\hline & $(0.15787)$ & $(51.10573)$ & $(0.00731)$ & $(1.58485)$ & $(0.02550)$ & $(3.6669)$ \\
\hline \multirow{2}{*}{ EFF } & -0.00369 & 0.03381 & -0.00007 & $-0.29633^{* *}$ & 0.00510 & -0.04293 \\
\hline & $(0.00349)$ & $(1.72987)$ & $(0.00072)$ & $(0.13058)$ & $(0.00507)$ & $(0.05968)$ \\
\hline \multirow{2}{*}{ NONIM } & -0.17992 & 57.75075 & $-0.09509^{* * *}$ & 8.167505 & 0.32324 & -2.571693 \\
\hline & $(0.30378)$ & $(55.36844)$ & $(0.01327)$ & $(5.27811)$ & $(0.61769)$ & $(4.25740)$ \\
\hline \multirow[b]{2}{*}{ ROA } & $-0.86782^{*}$ & ND & ND & $31.22167 * *$ & $2.62363^{* * *}$ & -10.74488 \\
\hline & $(0.52338)$ & & & $(13.29523)$ & $(1.03252)$ & (9.39699) \\
\hline \multirow{2}{*}{ ROE } & $0.13759^{* * * *}$ & $-19.65775^{*}$ & -0.00012 & $-2.59887 * *$ & $-0.21942 * *$ & 0.81540 \\
\hline & $(0.04425)$ & $(11.37003)$ & $(0.00342)$ & $(1.32391)$ & $(0.09783)$ & $(0.62786)$ \\
\hline \multirow{2}{*}{ DIV } & $0.00125^{*}$ & -0.07680 & $0.00017^{*}$ & 0.01675 & -0.00110 & 0.00868 \\
\hline & $(0.00076)$ & $(0.34164)$ & $(0.00010)$ & $(0.01670)$ & $(0.00106)$ & $(0.01357)$ \\
\hline \multirow{2}{*}{ SIZE } & 0.00099 & 0.37965 & 0.00071 & $-0.07148 * *$ & $0.002351^{*}$ & -0.02403 \\
\hline & $(0.00099)$ & $(0.35580)$ & $(0.00050)$ & $(0.030044)$ & $(0.00135)$ & $(0.03077)$ \\
\hline \multirow{2}{*}{ GDP } & 0.000014 & 0.02939 & 0.00001 & -0.0018 & $0.00069^{* * * *}$ & 0.00096 \\
\hline & $(0.00012)$ & $(0.06592)$ & $(0.00007)$ & $(0.00163)$ & $(0.00025)$ & $(0.00154)$ \\
\hline \multirow{2}{*}{ INF } & -0.00005 & -0.09206 & $0.00010^{*}$ & 0.00094 & $0.00058^{*}$ & -0.00078 \\
\hline & $(0.00011)$ & $(0.05861)$ & $(0.00005)$ & $(0.00173)$ & $(0.00031)$ & $(0.00133)$ \\
\hline Num. of obs. & 220 & 140 & 140 & 220 & 220 & 220 \\
\hline Sargan test & 6.1763 & 12.3999 & 8.3978 & 4.5661 & 6.6585 & 6.09475 \\
\hline P-value of Sargan test & 1.0000 & 0.9887 & 0.9996 & 1.0000 & 1.0000 & 1.0000 \\
\hline Arrellano \& Bond test AR (1) & -1.1769 & -2.3264 & -1.2516 & -1.6929 & -3.9017 & -0.9842 \\
\hline P-value d'AR (1) & 0.2392 & 0.0200 & 0.2107 & 0.0905 & 0.0001 & 0.3250 \\
\hline Arrellano \& Bond test AR (2) & -0.46997 & -0.61386 & -2.6884 & -0.57517 & -2.077 & -1.4441 \\
\hline P-value d'AR (2) & 0.6384 & 0.5393 & 0.0072 & 0.5652 & 0.0378 & 0.1487 \\
\hline
\end{tabular}

ND: independent variable is not defined in order to avoid the problem of multi-collinearity

\subsection{Interpretation of the Results}

All the panels use as variable of interest the securitization ratio (SEC) and use also at most the following control variables which are divided into two groups: bank-specific variables defined by capital adequacy (CAD), liquidity ratio (LIQ), net interest margin (NIM), return on assets (ROA), return on equity (ROE), on-balalncesheet interest rate risk (NONIM), efficiency (EFF), income diversification (DIV) and size, and country-specific variables defined by GDP and inflation (INF).

\subsubsection{Panel A1 Results}

In the Panel A1 we conduct regressions during the period 2007-2017 by choosing BSI as dependent variable. The results show that the relationship between BSI and SEC is positive at $10 \%$ level of significance. Therefore, we deduce that using securitization affects positively bank stability index of sample banks. In the same way, we find that the capital adequacy and income diversification of sample banks affect favorably their bank stability index. Indeed, our findings indicate that the effect of capital adequacy and income diversification on BSI is positive respectively at $1 \%$ and $10 \%$ levels of significance.

On the other hand, the results reveal an opposite effect of the two proftabiliy measures (ROA and ROE) on BSI so that the profitability has ambiguous effect on bank stability index of sample banks.

\subsubsection{Panel A2 Results}

In the Panel A2 regressions are conducted during the period 2007-2017 by using logarithm of zscore (LNZSCORE) as dependent variable. This variable is defined as proxy of stability. 
The results of this panel illustrate that the relationship between LNZSCORE and SEC is positive at $10 \%$ level of significance. As a result, we realize that using securitization affects positively logaritm of zscore of sample banks. Conversely, the findings of the Panel A2 demonstrate that ROE has negative impact on logaritm of zscore of sample banks at $10 \%$ level of significance. However, we remark that the effect of the rest of control variables on LNZSCORE is not significant. Thus, we deduce the weakness of logarithm of zscore as proxy of stability measure in our issue. Therefore, we suggest for further studies to choose other proxy of stability.

As summary, we deduce from the results of Panel A1 and Panel A2 that using securitization improves the stability of sample banks during the period 2007-2017. Hence, banks from emerging countries picks up their stability by using securitized instruments. As regards control variables, we deduce that - by diversifying their incomes - sample banks enhance their stability. Evenly, we deduce that sample banks have enough level of leverage which increases their stability.

\subsubsection{Panel B1 Results}

The Panel B1 uses as dependent variable Total risk which is proxied by standard deviation of ROA (SDROA). The findings of this panel reveal negative relationship between SROA and the ratio of securitization at 5\% level of significance. Consequently, we deduce that using securitization by sample banks affects negatively their Total risk. Equally, we find that NONIM affects negatively Total risk. However, CAD, LIQ, NIM, DIV and INF affect positively SDROA. Therefore, we deduce that capital adequacy, liquidity, net interest margin, income diversification and inflation increase the total risk of sample banks.

\subsubsection{Panel B2 Results}

In this panel we use a proxy of credit risk measured by the ratio of gross loans divided by total assets. The results of this panel show illustrate that the relationship between GL ratio and the securitization ratio is negative at $10 \%$ level of significance. Thus, the use of securitization by sample banks reduces their credit risk as measured by GL ratio. In the same way, we find that capital adequacy, liquidity, efficiency and size of sample banks decrease their credit risk as measured by GL ratio. On the other hand, we find opposite effect of the two profitability measures on GL ratio. Hence, the profitability of sample banks has confusing effect on their credit risk as measured by GL ratio.

\subsubsection{Panel B3 Results}

In this panel we use a proxy of credit risk measured by the ratio of loan loss provision divided by total loans. We find that the relationship between LLP ratio and the securitization ratio is negative at $10 \%$ level of significance. Thus, the use of securitization by sample banks reduces their credit risk as measured by LLP ratio. Similarly, the findings show that capital adequacy of sample banks decrease their credit risk as measured by LLP ratio. In the opposite, we find spositive effect of the size, GDP and inflation on credit risk as measured by LLP ratio. Finally, and equally to the previous panel, we find opposite effect of the two profitability measures on LLP ratio. Hence, the effect of profitability of sample banks on the credit risk as measured by LLP ratio is not obvious.

\subsubsection{Panel B4 Results}

In this panel credit risk is measured by the ratio of NPL by gross loans and used as dependent variable. We remark that all the explanatory variables do not have significant effect on the credit risk as measured by NPL ratio. Therefore, we suggest for further studies to do not use NPL ratio as credit risk measure when they study this issue.

\section{Summary of Main Results}

The results of the two panel A1 and A2 regressions reveal that the relationship between the securitization ratio and the measure of stability as defined by "BSI" and "logarithm of z-score" is significantly positive. .

As a result, we deduce that the banks in the sample improve their financial stability by using securitization products.

In addition, the conclusion of the B1 panel regression reveals that the relationship between securitization and total risk as measured by the "SDROA" ratio is significantly negative. This implies that the use of securitization by banks in our sample negatively affects their total risk.

In addition, the regression results of the two B2 and B3 panels show that the relationship between the securitization ratio and the two credit risk ratios "GL and LLP" is significantly negative. Thus, the use of securitization by the banks in the sample reduces their credit risk, measured by the GL ratio and the LLP ratio.

For panel B4, the regression results show that all explanatory variables do not have a significant effect on credit risk as measured by the ratio of bad loan impairments (NPL). As a result, we infer that there is no relationship between the securitization ratio and this credit ratio. 


\section{Conclusion}

In this study we empirically studied the effect of the use of securitization on financial stability and banking risk in emerging markets for the period 2007 to 2017. To do this, we performed a series of dynamic regressions using a GMM technique.

Our research work focused on a sample of 20 emerging market banks that are classified into three regions:

- South America (Mexico, Argentina, Brazil and Colombia),

- Asia (Kuwait, the United Arab Emirates, Lebanon, China, Taiwan, South Korea, the Philippines and India)

- and Africa (South Africa).

The main results of this work show that the use of securitization, by the banks in the sample, positively affects their financial stability and negatively their risks, in particular their total risk and their credit risk.

Thus, we can conclude that the use of securitization has a beneficial effect on banks from emerging countries in terms of improving their financial stability and reducing their total risk and credit risk.

However, the statistical study carried out during this work showed us that most banks in the sample use securitization in small proportions.

Therefore, and as a practical contribution to this work, we suggest that banks' decision-makers in emerging countries increase their use of securitization in order to benefit from its beneficial effect on their financial stability and risks.

Like all research, our research work has methodological and conceptual limitations. Indeed, the first limitation of our study lies in the fact that we decided to study the effect of securitization in the context of emerging countries. As a result, our conclusions are not necessarily transferable to other environments unless other studies demonstrate. A second limitation lies in the small number of banks constituting our sample. The third limitation lies in the fact that our research does not pretend to study extensively the use of securitization by other financial institutions other than banks, namely companies and insurance companies.

As theoretical contributions, we recommend future work:

- Choose new variables, other than the z-score log as a measure of stability and NPL ratio as a measure of credit risk, to obtain better results.

- To compare the banks of developed countries with those of emerging countries when they study this subject.

\section{References}

Agusman, A., Gasbarro, D., Monroe, G. S., \& Zumwalt, J. K., (2008). Accounting and capital market measures of risk: Evidence from Asian banks during 1998-2003. Journal of Banking \& Finance, 32(4), 480-488. https://doi.org/10.1016/j.jbankfin.2006.06.018

Arellano, M., \& Bover, O. (1995). Another look at the instrumental variable estimation of error-component models. Journal of Econometrics, 68, 29-51. https://doi.org/10.1016/0304-4076(94)01642-D

Battaglia, F., \& Gallo, A. (2013). Securitization and systemic risk: An empirical investigation on Italian banks over the financial Crisis. International Review of Financial Analysis, 1-13. https://doi.org/10.1016/j.irfa.2013.03.002

Blundell, R., \& Bond, S. (1998). Initial conditions and moment restrictions in dynamicpanel data models. Journal of Econometrics, 87, 115-143. https://doi.org/10.1016/S0304-4076(98)00009-8

Chiaramonte, L., Croci, E., \& Poli, F. (2015). Should we trust the Z-score? Evidence from the European Banking Industry. Global Finance Journal, 28, 111-131. https://doi.org/10.1016/j.gfj.2015.02.002

Chiaramonte, L., Poli, F., \& Oriani, M. (2013). Are Cooperative Banks a Lever for Promoting Bank Stability? Evidence from the Recent Financial Crisis in OECD Countries. European Financial Management, 9999, 1-33.

Deku, S. Y., Kara, A., \& Zhou, Y. (2019). Securitization, bank behaviour and financial stability: A systematic review of the recent empirical literature. International Review of Financial Analysis, 61, 245-254. https://doi.org/10.1016/j.irfa.2018.11.013

Dionne, G., \& Harchaoui, T. M. (2003). Banks' Capital, Securitization and Credit Risk: An Empirical Evidence for Canada. SSRN Electronic Journal, 1-37. https://doi.org/10.2139/ssrn.369501

Egoviano, M. A., \& Goodhart, C. A. E. (2009). Banking stability measures. IMF Working Paper No. 4, IMF, Washington, DC. 
Fu, X., Lin, Y., \& Molyneux, P. (2014). Bank competition and financial stability in Asia Pacific. Journal of Banking \& Finance, 38, 64-77. https://doi.org/10.1016/j.jbankfin.2013.09.012

Ghosh, A. (2017). How do derivative securities affect bank risk and profitability? Evidence from the US commercial banking industry. The Journal of Risk Finance, 18(2), 186-213. https://doi.org/10.1108/JRF-09-2016-0116

González, L. O., Rodriguez Gil, L. I., Mortorell Cunill, O., \& Merigo Lindahl, J. M. (2016). The effect of financial innovation on European banks' risk. Journal of Business Research, 69(11), 4781-4786. https://doi.org/10.1016/j.jbusres.2016.04.030

Illing, M., \& Liu, Y. (2003). Measuring Financial Stress. Financial System Review, 43-48.

Ivicic, L., Kunovac, D., \& Ljubaj, I. (2008). Measuring Bank Insolvency Risk in CEE Countries. Croatian National Bank Working Paper.

Jiangli, W., \& Pritsker, M. G. (2008). The Impacts of Securitization on US Bank Holding Companies. SSRN Electronic Journal, 1-58. https://doi.org/10.2139/ssrn.1102284

Kasman, A., \& Carvallo, O. (2014). Financial stability, competition and efficiency in Latin American and Caribbean banking. Journal of Applied Economics, XVII(2), 301-324. https://doi.org/10.1016/S1514-0326(14)60014-3

Kasman, S., \& Kasman, A. (2015). Bank competition, concentration and bank stability in the Turkish banking stability. Economic Systems, 39, 502-517. https://doi.org/10.1016/j.ecosys.2014.12.003

Laeven, L., \& Levine, R. (2009). Bank governance, regulation and risk taking. Journal of Financial Economics, 93, 259-275. https://doi.org/10.1016/j.jfineco.2008.09.003

Liu, H., Molyneux, P., \& Wilson, J. (2010). Competition and stability in European banking: A regional analysis, Preliminary Draft. https://doi.org/10.2139/ssrn.1670744

Michalak, T. C., \& Uhde, A. (2012). Credit risk securitization and bank soundness in Europe. The Quarterly Review of Economics and Finance, 52(3), 272-285. https://doi.org/10.1016/j.qref.2012.04.008

Mokatsanyane, D., Muzindutsi, P. F., \& Viljoen, D. (2017). Credit Risk and Securitisation in the South African Banking Sector. Financial Institutions and Services, 13(2), 1-20.

Morris, V. C. (2011). Measuring and forecasting financial stability: The composition of an aggregate financial stability index for Jamaica. Business, Finance and Economics in Emerging Economies, 6(2), 34-51.

Sere-Ejembi, A., Udom, I. S., Salihu, A., Atoi, N. V., \& Yaaba, N. B. (2014, June). Developing Banking System Stability Index for Nigeria. Journal of Applied Statistics, 5(1).

Uhde, A., \& Michalak, T. C. (2010). Securitization and systematic risk in European banking: Empirical evidence. Journal of Banking \& Finance, 34, 3061-3077. https://doi.org/10.1016/j.jbankfin.2010.07.012

Van den End, J. W. (2006). Indicator and boundaries of financial stability. DNB Working Paper No. 97.

\section{Notes}

Note 1. Annual reports of South Rand Bank of South Africa in 2017, 2012 and 2007 uploaded via the website https://www.firstrand.co.za/

Note 2. Annual reports of Bank BBVA Bancomer of Mexico in 2007 and 2017 uploaded via the website https://www.bbva.com.co/

Note 3. Annual reports of the bank FransaBank of Lebanon in 2007 and 2017 downloaded via the website http://www.fransabank.com 